Historic, Archive Document

Do not assume content reflects current scientific knowledge, policies, or practices. 



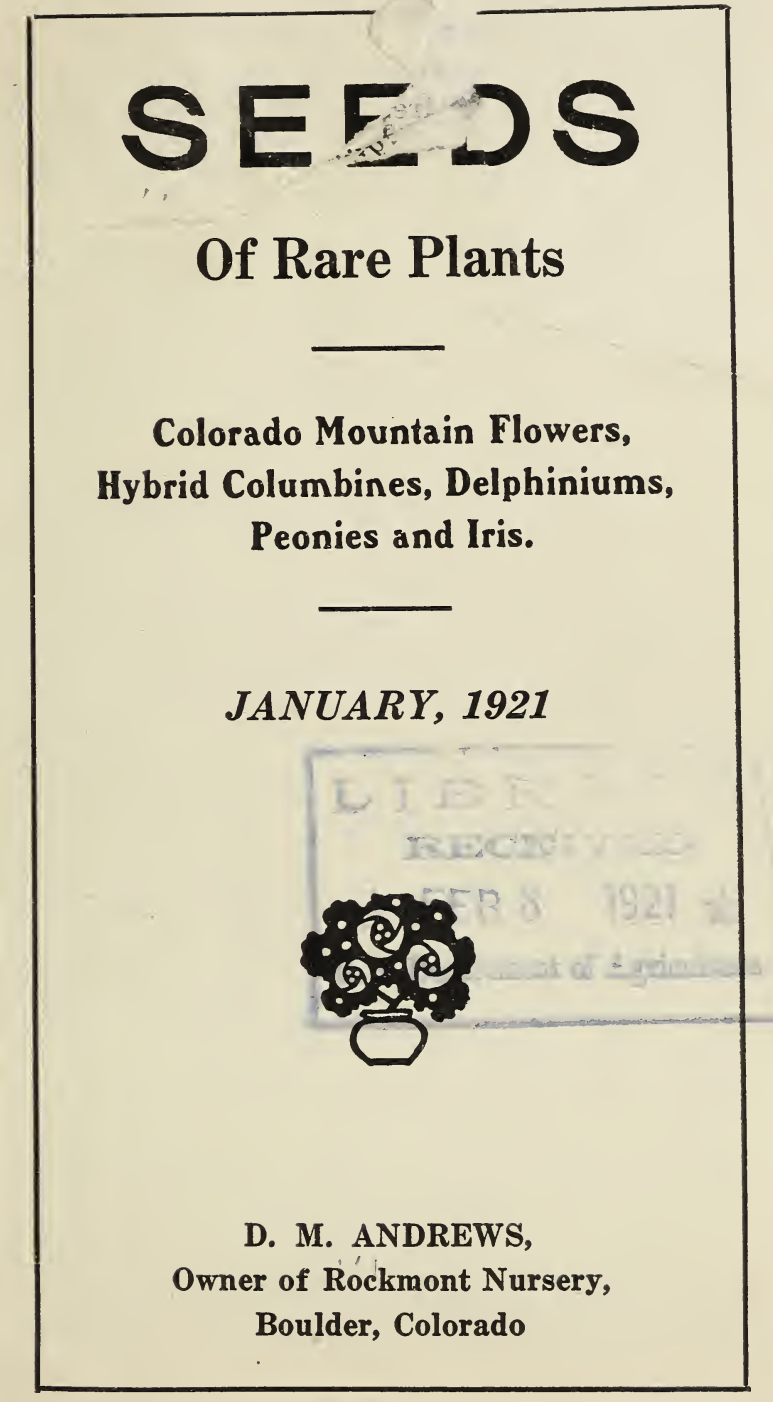




\section{INFORMATION AND TERMS.}

Prepaid-Seeds will be mailed prepaid to any post office address, except that a service charge of 10 cents ad itional for postage and packing should be incluaied with all orders amounting to less than $\$ 1.00$.

Remittances-Kindly send cash with order. I do not intend to open charge accounts for seeds, and can only undertake to do so as an accommodation. If an itemized invoice is required, add $5 \%$ to the amount for clerical work. Remit by check or money order if convenient, but 1-cent or 2-cent stamps will be accepted for small amounts.

Non-Warranty-I sell seeds in good faith, believing them to be of sound quality and otherwise as represented. The culture of our native flowers from seed may or may not be successful under your particular conditions; although they have as a rule succeeded in most of the northern and eastern states and in England. In supp?ying the stock offered in this catalogue I take it for granted that the buyer is a good sport and will accept occasional failure as unavoidable. Errors in filling orders will be rectified if reported promptly.

Free-I wish to become acquainted with any of your friends who are really progressive flower growers, and will thank you for an introduction. More than that, if you will send me at once five such addresses, I will mail free any 25-cent seed packet offered in this catalogue, whether you order other seeds or not. I do not buy lists of addresses; only five from one customer, please.

Address all correspondence and seed orders to

\section{M. ANDREWS, \\ Box 493, \\ Boulder, Colorado.}




\section{BEFORE MARCH FIRST, NOT LATER.}

A circus is not a circus without a clown, and a hobby supplies an equivalent diversion for the professional or business man that the clown does for the children. I confess to having two hobbies, and one of them is fishing. Fishing must be done in season and not out of season. When I go fishing in the summer I take a pocket full of paper bags and gather seeds of the beautiful wild flowers as I find them ripe along the mountain streams and roadsides. The Rainbow Trout and the rainbow-hued flowers appeal to me quite irrestibly.

For some time I have gathered no seeds for sale, but with the opening of our Rocky Mountain National Park, of which Boulder is a gateway, it seems more than probable that visitors to the park will be glad to grow these charming flowers at home, or present a few packets of seed to their friends. I shall be glad to undertake the distribution of the seeds which I gathered last summer, and the "open season" will be the two months of January and February.

As you will have guessed, this is not my principal business, but merely a side line or hobby, personally conducted for my pleasure and yours. Therefore, I emphasize my headline, "Before March First, Not Later." After March first, my nursery business will require my entire attention. So please do not fail to hand me your order early, while I can assure prompt attention and a complete stock.

\section{OTHER CATLOGUES.}

Besides this seed list there will be issued in February the General Catalogue of Rockmount Nursery. It is intended for a high class local trade, and offers superior home grown stock of shade trees, evergreens, hardy shrubs, vines and perennial plants adapted to the requirements of the Rocky Mountain region.

Late in summer will appear my autumn catalogue of Peonies and Iris, including a very 
complete list of choice novelties as well as the standard sorts. Lilies and other stock best suited for fall planting will be included.

Rockmont Nursery makes a specialty of growing the best native shrubs of the Rocky Mountains. These include choice material for decorative planting. Most of them are rare in eastern gardens, and some have never been offered for sale. If interested; please write me. The response to this announcement will help determine when a catalogue of native shrubs will be issued.

Any of these catalogues will be mailed free when ready, but please specify which are wanted.

\section{COLORADO MOUNTAIN FLOWERS.}

The culture of perennials from seed differs from annuals mainly in the length of time required. It is important therefore, to provide for perennials a seed bed filled with soil of good mechanical texture, so that it will not pack or bake during the period of use. Lath shades or other slight protection is beneficial during the germinating period and in hot weather. Means for artificial watering should be available, as seeds during germination and young seedlings cannot endure much drought without severe loss. The seeds of some species remain dormant over one season, so ample time should be given any whose germination is delayed. Many perennials germinate quickly, and some will bloom the first season if sown early.

As most of the Mountain Flowers will thrive in a calcareous soil, and some kinds demand such, the addition of a small quantity of lime to the seed bed, well mixed with the soil is recommended. Ground lime stone at the rate of a large handful to the square yard is best, but crushed lime mortar or thoroughly air-slaked lime may be substituted.

The kinds designated as rock plants require good, free drainage; this does not mean that they require the association of rocks. 
Many such plants grow naturally on slopes in ordinary soil. Vernal plants whose growth is completed by midsummer should have as little moisture as may be during their resting period. Most plants recommended for shade have naturally a soil rich in humus. An ordinary mellow loam is indicated for Colorado plants unless otherwise mentioned.

\section{Price of Seeds.}

All the Colorado Mountain Flowers are sold at 25 cents per packet, and $\$ 1.00$ per Trade Packet, containing five times the amount of a small packet. Of the small seeds like Colum. bine, Larkspur, etc., a packet will usually contain 200 seeds, or more, and a trade packet, 1,000 or more; but some of the rarer kinds and those having large grains must necessarily contain a smaller number. I call attention of extensive growers to the kinds offered by weight. Please order by number, or by name in black-faced type.

\section{GOLDEN ASTER-Chrysopsis.}

101 Chrysopsis amplifolia - One-foot clumps,, flowers showy and profuse, late summer.

\section{SQUAW ASTER-Senecio.}

102 Senecio Douglasii-Two feet, annual or perennial, early autumn.

VIOLET ASTER-Machaeranthera.

103 Machaeranthera aspera-Annual or perennial, 2 feet, large-flowered, showy, violet-pur. ple asters in rich profusion; early autumn.

\section{BEE PLANT-Cleome.}

104 Cleome integrifolia-Tall, branching, annual, lilac-purple sprays. ( Ounce, \$2.00.)

105 Cleome integrifolia alba-Pure white.

BLUE BELL-Campanula, Mertensia.

106 Campanula rotundifolia-Harebell; 1 foot, summer-flowering rock plant. 
107 Mertensia lanceolata-(Syn. papillosa.) Neat clumps, 1 foot, for dry rockery; free bloomer in elegant drooping sprays, early spring.

108 Mertensia pratensis-Lungwort. Two feet, half shade, moist or dry soil, stout, erect habit, green foliage (not glaucus), a profusion of blue bells in graceful, declining sprays; new, distinct type, easily grown.

\section{BUFFALO PEA-Thermopsis.}

109 Thermopsis rhombifolia - One foot, early, bright yellow pea blossoms in showy racemes. (Ounce, \$3.00.)

110 Thermopsis montana-Taller, larger and later; fragrant. (Ounce, $\$ 3.00$ ).

GOLDEN CARAWAY-Harbourla.

111 Harbouria trachypleura - Neat rock plant, 1 foot, graceful yellow sprays, feathery foliage, dry sunny position.

\section{CLEMATIS.}

112 Clematis coccinea-Vine, scarlet bellshaped blossoms all summer. (Ounce, \$1.50.)

113 Clematis crispa, lavender-Vine, simllarto the last, but flowers lavender, with wavy or crisped margins; all summer.

114 Clematis crispa, purple-(Ounce, \$1.50.)

115 Clematis Fremontii-Bush, 1 foot, broad foliage, bell-shaped lavender or purple flowers.

116 Clematis integrifolia-(Not native.) Bush, 1 foot, large flat blue flowers all summer. (Ounce, \$1.50.)

117 Clematis Ilgusticifolia-Woody vine, white flowers and seed sprays.

COLUMBINE-Aquilegla.

118 Aquilegia coerulea-Two feet, half shade, humus soil. A succession of seedlings should be grown each year, as young plants produce the finest flowers. A marvel among 
Columbines-4-inch blossoms contrasting the color of blue sky and summer cloud. These clear colors and magnificent size can be obtained oniy from my pure-bred strain direct from the Mountains of Colorado. (Ounce, $\$ 2.00$; pound, \$25.00.)

\section{CRANESBILL-Geranium.}

119 Geranium Fremontii - Summer-bloom. ing, clump-forming, hardy perennial, lilac or purple.

\section{EASTER DAISY-Townsendia.}

120 Townsendia grandiflora-Low rock plant for warm, sunny position, sandy soil; very showy, early summer bloomer.

\section{EVENING PRIMROSE-Oenothera.}

121 Oenothera brachycarpa-Pretty rosetteforming rock plant for dry ground; 4-inch yellow blossoms among the foliage turn to orangescarlet with age. Seeds germinate slowly.

EVENING STAR-Mentzelia.

122 Mentzelia chrysantha - Bushy rock plant, 1 foot, for light soil, flowers golden yellow, showy.

123 Mentzelia decapetala-(Syn. ornata.) Startlingly beautiful 5-inch flower of creamy white, formed like a cactus blossom with ten petals and thread-like stamens. Branching biennial or perennial, 2 feet tall; late summer and autumn; calcareous soil. Sow seeds where plants are to bloom.

\section{DESERT FORGET-ME-NOT-Oreocayra.}

124 Oreocayra suffruticosa-Low tufted rock plant for dry, sandy soil. Grayish foliage, small white flowers with yellow eye.

\section{GENTIAN-Gentiana.}

125 Gentiana Andrewsii-One foot, moist 8oil, flowers clustered, showy, pale blue.

126 Gentiana elegans-Western Fringed Gentian, of wet mountain meadows. Biennial, requiring same culture as eastern variety; the 
most beautiful American species but not easily cultivated.

127 Gentiana Parryi-Stout sub-alpine species, requires moist, turfy soil; clusters of large flowers of intense blue.

\section{GILIA.}

128 Gilia pungens-A tufted desert perennial for dry sunny rockery in sandy soil. Resembles Phlox subulata in habit and flower, color straw-white.

\section{GOLDEN ROD-Solidago.}

129 Solidago rigida-Stout, non-spreading, 2 feet, with showy, flat-topped corymbs.

130 Solidago spectabilis-One to two feet, elongated panicle, non-spreading, very fragrant; dry rockery or border; best garden sort.

\section{HEARTEASE-Polygonum.}

131 Polygonum bistortoides - Heads of small white or tinted flowers on slender stems from a rosette of glossy foliage; neat rock plant or border perennial.

\section{HYACINTH PEA-Oxytropis.}

132 Oxytropls hybrida-Slender Hyacinthlike racemes of pea-shaped flowers on onefoot stems from a rosette of pinnate, silvery foliage. Established clumps often produce 20 to 30 flower stems in a single season. This hybrid strain has flowers of the character of wisteria, but the racemes and individual flowers are somewhat smaller. They vary in color from pure white, pale rose, lavender and shades of purple to crimson. Sandy loam preferred, to which lime should be added. (1/4-ounce, $\$ 1.00$; ounce, $\$ 3.50$.)

133 Oxytropis villosus - (Loco plant.) Creamy-white, dwarf, very silky foliage, same culture.

\section{IRIS.}

134 Iris Missouriensis-Dwarf, early flowering native, large lavender blossoms; recom- 
mended as a rock plant where it can be dried off after flowering. (Ounce, $\$ 2.00$.)

\section{LARKSPUR-Delphinium.}

135 Delphinium elongatum - Four feet, showy dark blue flowers in very long racemes; moist ground.

136 Delphinium Geyeri-Three feet, bright, intense blue, silver-gray foliage; dry slopes. (1/4-ounce, $\$ 1.00$; ounce, $\$ 3.50$.)

137 Delphinium Penardii-Two feet, long racemes of white flowers, dry soil.

\section{LUPINE_Lupinus.}

138 Lupinus alpestris - Dwarf, b u s h y clumps, dry mountain slopes, flowers light or deep blue. Add lime to the soil for Lupines.

139 Lupinus argenteus-Two feet, bushy, with silvery palmate foliage. Showy peashaped blue flowers, abundantly produced; dry soil.

140 Lupinus .decumbens-Broad clumps, flowers light blue or lilac. (Ounce, \$1.50.)

141 Lupinus decumbens albus-Pure white.

142 Lupinus glabratus-Distinct dwarf species with large, showy flowers; very rare.

\section{INDIAN MALLOW-Sidalcea.}

143 Sidalcea candida-Long racemes of 1 . inch white flowers on tall stems from bold clump of geranium-like foliage. (1/4-ounce, $\$ 1.00$.)

MONKEY FLOWER-Mimulus.

144 Mimulus Langsdorfii-A low sub-alpine for wet ground or water edge, bearing all summer a profusion of showy, golden yellow, ringent flowers; blooms a few months from seed.

\section{PENTSTEMON.}

145 Pentstemon accuminatus-Showy lilac flowers, 1-foot stems, glaucus foliage; dry sunny rockery.

146 Pentstemon albidus-Dwarf, for dry rockery; rare species, flowers white. 
147 Pentstemon alpinus-Deep azure-blue flowers in a low, crowded raceme; an exceed. ingly showy rock plant, or will grow in any light soil.

148 Pentstemon coeruleus-Dwarf, flowers sky-blue, or rose-tinted, in dense racemes; dry sandy soil.

149 Pentstemon gracilis-Low herb of moist meadows; showy lilac or lavender flow. ers.

150 Pentstemon unilateralis-Two feet, large purple flowers in long one-sided racemes. (1/4-ounce, $\$ 1.00$.)

\section{POLEMONIUM.}

151 Polemonium mellitum-A neat, tufted rock plant, best in partial shade. Flowers very pretty, in showy clusters, straw-white, honeyscented. Easily grown in any well drained loam. (1/4-ounce, \$2.50.)

\section{SILVER POPPY-Argemone.}

152 Argemone hispida-One foot, branched clumps, blue-green spiny foliage, magnificent white poppy blooms. Perennial in dry, sandy, calcareous soil, full sun. Sow seed where plants will bloom. (Ounce, \$1.00.)

153 Argemone platyceras-Two feet, glaucus silvery foliage, large satiny-white blooms, all summer. Will grow in almost any sunny place, not too moist. (Ounce, $\$ 1.00$.)

\section{PUCCOON-Lithospermum.}

154 Lithospermum albicans-One foot, pale green foliage, dry soil; long-tubular flowers, bright yellow. (1/4-ounce, \$1.00.)

155 Lithospermum multiflorum-B u s h y clumps a foot tall with tubular flowers like Mertensia in terminal sprays, but bright golden yellow. Very profuse bloomer most of the summer; a valuable and easily grown plant for rockery or border.

\section{SALVIA.}

156 Salvia azurea grandiflora-Azure-blue, 3 to 4 feet, late summer; blooms first season. 
One correspondent says, "You do not praise it half enough." (Ounce, $\$ 2.00$.)

SNOW-ON-THE-MOUNTAIN-Euphorbia.

157 Euphorbia marginata-Stout annual, the floral leaves prominently margined white. Calcareous soil. (Ounce, \$2.00.)

SUNFLOWER-Helianthus, Helianthella.

158 Helianthus pumilus-Summer-blooming perennial, only two feet tall. (Ounce, \$2.00.)

159 Helianthella quinquenervis-Early summer, large flowering, pale yellow, star-like, 3foot stems; very attractive perennial and easily grown.

UMBRELLA FLOWER-Eriogonum.

160 Eriogonum umbellatum - Mat-forming cover plant for dry soils, from which spring up many 6-12-inch stems bearing umbrella-like umbels of sulfur-yellow flowers which deepen with age to golden bronze; may be dried as an everlasting; foliage nearly evergreen. (1/4. ounce, \$1.25.)

\section{VERBENA.}

161 Verbena bipinnatifida - Low clumpforming rock plant, with the habit of the garden verbena; showy lilac-purple flowers all summer.

\section{FLOWERING VETCH-Astragalus.}

162 Astragalus bisulcatus-One-foot clumps, pinnata foliage, pea-shaped flowers in close racemes; dry, calcareous soil.

163 Astragalus Drummondii-Same habit, but larger flowers, silky gray foliage.

\section{VIOLET.Viola.}

164 Viola Nuttallii-A tufted, free-blooming, yellow violet for dry, sunny rockery. (1/4-ounce, \$1.25.)

\section{YUCCA.}

165 Yucca glauca-Extremely hardy species for rockery or dry ground. (Ounce, 50 cents.) 


\section{CROSS-FERTILIZED SEEDS}

\section{Of Columbine, Delphinium, Iris, Peony.}

Plant breeding has received a new impetus since the methods have been simplified and made more certain through the rediscovery of Mendel's laws of inheritance.

It is quite possible, with the seeds here offered, for the amateur to enjoy the wizzardry of horticulture and produce floral creations in his own garden. The great problem has been heretofore to secure seed which could be depended upon for superior results.

Colorado has the climate which excels in the development of fertile pollen and of sound, plump seeds. Consequently, cross-fertilization is readily accomplished with maximum results. On my own grounds the excellent soil together with modern facilities and conveniences afford laboratory conditions. My collections at Rockmont Nursery are ample in quantity and represent the highest types of new and old varieties in the groups offered. By special methods I am securing cross-fertilized seeds which have given exceptional results in my own cultures. I have never before offered any of these seeds for sale, having had no surplus. The quantity I can now spare is limited, and to prevent waste let me urge that orders be received only from those who have fairly good facilities for growing to maturity.

\section{HYBRID COLUMBINES. -}

The best of the hybrid Columbines are derived from crossing and recrossing of four original species of Aquilegia. All of these are native of the western United States and Mexico. Coerulea, blue with white center, is the North. ern Rocky Mountain type. Its dominant char. acter, transmitted to its hybrids, is large size of flower. Chrysantha, yellow, is from the Southern Rocky Mountain region, and its vigor, longevity and persistent flowering habit invariably characterize its hybrids. Truncata, scarlet and yellow, from the Pacific coast, is early 
and its chief contribution is color. In repeated crossing with other species and hybrids the coior combinations become exceedingly com. plicated; rare shades of pink and rose show the influence of this species. Skinneri, scarlet and yellow with green calyx tips, is a native of Mexico. It is later than Truncata, taller and the most robust of all. From its complex crosses with Coerulea hybrids are derived the very rich cardinal, crimson and purple shades with yellow centers. These with their sturdy, erect habit, large size of flower and freedom of bloom exemplify the superlative attainment in hybrid Columbines.

Ordinary Columbine hybrids show a tendency to run too much to yellow and pale tints of indefinite character. While this cannot be avoided entirely, I have succeeded in reducing it to a minimum. The hybrids I offer are the result of much repeated crossing. They are all several generations removed from the original species and their genealogy is therefore complex. The seeds saved from certain color types cannot come uniformly true, but a11 variations from type will reflect their superior ancestry and will be sure to please.

The following hybrid selections are offered this season. As just stated, only part of the hybrid seedlings can be expected to come true to color. Price, all varieties: packet 200 seeds, 25 cents; trade packet 1,000 seeds, $\$ 1.00$.

Coerulea Hybrids-These include bicolored types with white or yellow centers, and some will quite closely resemble the Coerulea parent, but with improved vigor.

Pink, Salmon and Rose-Perhaps the most admired of all our hybrids; bicolor types with white or yellow centers.

Scarlet, Cardinal and Purple-With white or yellow centers. A superb blend of rare colors which perhaps has never been equaled. 
Yellow, Cream and White-Saved from extra choice types in these colors.

Rainbow Mixture-Nothing finer in long. spurred hybrid Columbines has been produced. Not an ordinary mixture, but a blend carefully proportioned from distinct types saved separately; to which is added the seeds from various unclassified hybrids marked when in bloom.

Ordinary Mixture-Equal to the best commercial grades and desirable for naturalizing, or where low cost is the consideration. (Ounce, $\$ 2.50$.)

\section{HYBRID DELPHINIUM OR LARKSPUR.}

Before the Federal Quarantine No. 37 became effective, I had acquired from abroad a collection of the choicest named varieties of Delphinium, from which I have grown many seedlings of surpassing excellence. From the first I have avoided the exceedingly tall forms characteristic of the so-called Gold Meda: or elatum strains, and have retained only those of medium height with rather condensed inflorescence; of which the variety Queen Wilhelmina may be taken as a type. My seedlings now maintain quite uniformly this medium and stocky habit and exhibit a maximum range of color, including white, light, bright and deep blue and rare rose and plum tints. A large percentage come double, among which, bicolored flowers are frequent. I believe this strain to be distinct from any other offered, and I confidently recommend it to every lover of Delphiniums. Care should be taken to preserve all the smaller seedlings if double flowers are desired. Packet, 200 seeds, 25 cents; trade packet, 1,000 seeds, $\$ 1.00$.

\section{IRIS HYBRIDS.}

Iris seedlings are easily grown and bloom the second or third year. The ease and certainty with which charming new varieties can be obtained has attracted many to the growing of seedlings. My rows of seedlings at Rockmont Nursery made a more brilliant display 
and attracted more attention last summer than a large field of named varieties. I will offer this season a blend of Tall Bearded or German Iris, saved from my collection of named varieties and from my own choice seedlings. Packet, 25 cents; one ounce, $\$ 1.00$.

\section{HYBRID PEONY SEEDS.}

No branch of floriculture is more fascinating than the creation of new varieties of peonies from seed. The length of time required should not deter anyone, because successive plantings each season will soon bring an annual procession of prospective prize-winners.

It is of course unnecessary to suggest that a few seeds of the right parentage are worth more than a quantity of ordinary stock, with the added advantage that better care and more space can be given to those that are really worth while.

Hybrid peony seedlings are sometimes characterized by exceptional vigor, but quite as often they appear weak and develop normal strength slowly. The more diminutive baby peony is not necessarily a weakling. Its annual advancement may be slow and it may come into bloom several seasons later than more precocious individuals. But when its character is fully determined it is quite likely to manifest a general superiority. My own records indicate that my choicest full double seedlings have come from those which made haste slowly. To obtain the best results from hybrid peony seed, great care should be taken to secure complete germination of all seeds planted, and to make sure that none of the weaker plants are destroyed by over-crowding, or neglect.

Peony seeds usually remain dormant over one season. Plant an inch deep, an inch apart, and transplant when one year old. The seed bed should not become very dry at any time. A mulch of evergreen boughs or excelsior is 
recommended, but this should be removed before the seedlings appear.

Superb Double Peonies-The seeds from twenty-four double named varieties constitute this mixture, among which are Felix Crousse, Floral Treasure, Giganthea, Jeanne d'Arc, Mons. Boucharletaine, Meissonier, Richard Carvel, Umbellata Rosea, and others equally good. No single nor half-double are included. None of these produce seed very freely. Nearly all are without stamens. Bees carried the pollen from other flowers, among which Marie Jacquin contributed largely. From this same strain of otner years I have grown new seedling varieties which are in no respect inferior to the world's best when cultivated under identical conditions. Some of these are sufficiently distinct from existing varieties to warrant high commercial rank as soon as they can be introduced. I recommend this stock both to amateur and professional growers. Price, per packet, of 100 seeds, $\$ 1.00 ; 1,000$ seeds for $\$ 7.50$.

Single and Japanese Peonies-From the best sing ${ }_{1}$ types and the best named Japanese, carefully blended to give the greatest possible variety. Includes Snow Wheel, King of England, Mikado, etc. Price, per packet of 100 seeds, 50 cents; 1,000 seeds for $\$ 3.50$.

Mixed Peonies-From kinds which produce seed freely and which are not included above. AS peony seedlings derive their inheritance equally from pollen parent and from seed parent, this stock offers high possibilities, but will doubtless carry a larger percentage of single and half-oduble flowers. Price, per packet of 100 seeds, 25 cents; 1,000 seeds for $\$ 1.75$. 